Article

\title{
Vibing with Blackness: Critical Considerations of Black Panther and Exceptional Black Positionings
}

\author{
Derilene (Dee) Marco \\ Media Studies Department, University of the Witwatersrand, Johannesburg 2000, South Africa; \\ Dee.Marco@wits.ac.za \\ Received: 12 September 2018; Accepted: 15 November 2018; Published: 21 November 2018
}

\begin{abstract}
This article considers different ways in which Blackness is represented as exceptional in the 2018 film Black Panther. It also considers other iterations of Black visibility and legibility in the current popular culture context which appears to privilege Black narratives in interesting ways. The essay uses conceptual lenses from diaspora studies, Afro science fiction and Black feminist studies to critically engage the film and to critically question the notion of Black exceptionalism.
\end{abstract}

Keywords: Afrofuturism; blackness; Black exceptionalism; cinema; post-apartheid; Black Panther film

\section{Introduction}

How do you know I'm real? I'm not real. I come to you as myth, because that's what black people are-myths.

$\operatorname{Ra}(2017)$

Gabi Ngcobo holds the position as the first Black curator of the Berlin Biennale. In various articles from South African and other global publications, the overarching message about the Biennale was its (and its curator's) exceptionalism. This exceptionalism, it seems, is to be read as a slightly nervous celebration of Ngcobo as Black and an equally anxious reception of her all black team and a host of seemingly 'unknown artists' who were on the show. Ngcobo herself confronts this geographical and psychological positional through the following - a position that I wish to use in this article as a basis and space for reflection:

... To be seen as only a black team means Europe is still making itself the center. It's important, for me at least, not to think of [Europe] as the center of power. My context, which is South Africa and Johannesburg, is my center. And when I start to think, I think from that center...there are knowledge systems that have been repressed for such a long time. (City Press, Blignaught 2018)

Celebration of Black exceptionalism and black trauma from predominantly Western centers means that, as Ngcobo articulates, we are still, traditionally and predominantly, taught and understood to think from the West as center. Ngcobo, as curator and prime creator of the biennale, is about more than her being a woman. It is part responsibility, placed at her doorstep by an art world, and a cultural-political space that has become more aware of the problems of the part in the present. In an article for Artnet news, Ngcobo and Sao-Paulo based curator, Thiago de Paula Souza, who was part of the curatorial team, both argue for their position as one which is distinctively not about "fixing the mess" and which refuses to "exorcise Europe's colonial ghosts" (Brown 2018). These vehement disavowals of responsibility have placed Ngcobo and her team in a rather challenging position in that they still had to put together the show. The intention of this paper starting from this vantage 
point, one partially in the diaspora and partially thinking about contemporary representations of Blackness, is to place the consideration of Black exceptionalism at the forefront of the discussion. In other words, Ngcobo and her team are very aware of how their positions could be used to make certain Western/European histories legible and to fix histories.

In traditional institutions and spaces of authority and power, Blackness is still read as Otherness. Black feminist scholar, Bell hooks, critically identified and engaged some of these representations in 1989 when she wrote about "white-supremacist, capitalist patriarchy" (hooks 1989). In 2017, Black feminist scholar Sara Ahmed engages some of the same ideas when she writes about which kinds of bodies fit in. Ahmed writes: "If we have a body that is expected to turn up, we might be less likely to be caught by what comes up ... When you don't fit, you fidget. How quickly the fidgeting body appears to be not residing in the right place. Eyebrows are raised. Really; really? Are you sure?" (Ahmed 2017, p. 132)

Ahmed's articulations about the body out of place can be traced back to Fanon's theorization about race in (Fanon 1967) Black Skins, White Masks but has found various iterations in theory and practice since. My intentions for starting this chapter with this theoretical approach located in cultural studies about race and otherness in cinema and specifically in the 2018 Marvel film, Black Panther (Ryan Coogler), is about keeping this approach in mind when discussing popular culture expressions of black (popular) culture and, what can only be described as Black exceptionalism. In particular, I am interested in how and when we see what Ahmed articulates through the question, "Really; really? Are you sure?", for this echoes a particular performance of whiteness towards black bodies in positions which they hold now but positions which were historically embodied by white people.

Keeping in mind this Special Issue's focus on post-apartheid visual culture, the essay attempts to combine some of Ngcobo's experiences as outlined above, with the Hollywood adaptation of the Marvel comic Black Panther. The essay attempts to filter through some of the rather larger conceptual concerns and decisions Ngcobo had to make, while at the same time critically engaging the worldwide celebration of various black-centered films in Hollywood over the past few years. I refer to films with Black protagonists which to some degree problematize race and whiteness. Films like Get Out (Jordan Peele 2017) and 12 Years a Slave (Steve McQueen 2013), pushed the boundaries of representations of race and blackness in mainstream cinema and popularized seeing black people on screen in ways that had not been done before, where blackness was not only a subject to be subverted. Black Panther's marketing and thus appeal to a wide audience has not been very different to the aforementioned films and has yielded both celebration and conversation. Reviewer Steven Thrasher frames it in an interesting way when he describes Black Panther as Star Wars for black people. (Thrasher 2018) The recent years' deluge of films about race is partly contemporary popular culture and partly in response to the global sociopolitical context. This paper critically engages representations and celebration of Blackness, and thus tries to speak to and draw on Black sensibilities in this era of awareness and political correctness. We experience these films, this kind of cinema, in very particular curated ways too; in some ways, these films ask the viewers to help with the exorcism of histories of slavery, pillage and death. While we may assume a film such as Black Panther speaks from the position of a very particular kind of black experience, we need to remain aware of some of the ways this watching can be exploited and spectacularized, even as such films perform the work of building (critical) racial rapport. Drawing on Sara Ahmed in her writing about structural racism, I read the spectacular in this sense as Ahmed theorizes when she writes about building rapport as a "requirement because of a stereotype ... ". (Ahmed 2017, p. 130) Once a rapport has been built, it becomes easier to 'accept' an 'other', and even to critically engage whiteness. This essay thus attempts to engage notions of spectacular Blackness in a myriad of ways, keeping in mind positionalities of power and popular media's role in propagating awareness or 'lit' sensibilities. This concern is huge in post-apartheid South Africa; however, I chose to think about these ideas with the film Black Panther because of its reach and global value-South Africa no less affected by the film than other parts of the world. 


\section{Afrofuturism}

The notion of Afrofuturism gives rise to troubling antinomy: Can a community whose past has been deliberately rubbed out, and whose energies have subsequently been consumed by the search for legible traces of its history, imagine possible futures? (Dery 1994, p. 181)

Afrofuturism is a multimodal term which is used to describe certain kinds of science fiction films with Black futurist sensibilities at their core, a genre of its own, and a term which is increasingly a body of scholarship about such films. As Lisa Yaszek notes, it was really the period of the late 1990s that saw an emergence in Afrofuturism studies, when critics and scholars such as "Mark Dery, Greg Tate, Tricia Rose, and Kodwo Eshun first drew attention to the centrality of science fiction themes and techniques in the work of may black authors, artists, and musicians".(Yaszek 2006, p. 41) Often credited as the critic who coined the term, Mark Dery offers a two pronged definition of Afrofuturism in his 1994 edited volume, Flame Wars: The Discourse of Cyber Culture'. Dery is both invested in Afrofuturism as closely related to science fiction as an aesthetic genre and at the same time, politically invested in Afrofuturism as "a larger aesthetic mode that encompasses a diverse range of artists working in different genres and media who are united in their shared interest in projecting black futures derived from Afrodiasporic experiences" (Dery 1994, p. 136, in Yaszek 2006, p. 42). Afrofuturism is, in its very nature, interdisciplinary and encompasses a host of different positions and conceptual threads. (Eshun 2003). Ytasha Womack describes Afrofuturism as offering a "'highly intersectional' way of looking at possible futures or alternative realities through a black cultural lens. It is non-linear, fluid and feminist; ... Afrofuturism blends the future, the past and the present" (The Guardian, Thrasher 2015). Practicing this interdisciplinarity, Alondra Nelson's critical work with artist Paul D. Miller has seen the pair create the Afrofuturist listserve (Nelson and Miller 2006), a platform to access a plethora of information and which has facilitated Afrofuturism scholarship as a growing area of enquiry and theoretical contribution. Yaszek's consideration of the developments in Afrofuturism as political and aesthetic are useful when she writes the following:

Afrofuturism has evolved into a coherent mode not only aesthetically but also in terms of its political mission. In its broadest dimensions Afrofuturism is an extension of the historical recovery projects that black Atlantic intellectuals have engaged in for well over 200 years. According to author Toni Morrison, these projects do more than simply combat the erasure of black subjects from Western history ... Thus Afrodiasporic histories insist both on the authenticity of the black subject's experience in Western history and the way this experience embodies the dislocation felt by many modern peoples ... Afrofuturism holds the potential to bring the Afrodiasporic experience to life in new ways. (p. 47)

Keeping the above in mind, the article now focuses on the film Black Panther, a Marvel comic adaptation about the kingdom of Wakanda and T'Challa (Chadwick Boseman), a black protagonist and superhero with an all-female army. Black Panther was celebrated as exceptional for its representations of black characters, black women, a black superhero and the way in which a fictional black nation exists and enacts its power in a dystopian future. In the context of popular and widely commoditized Afrofuturist films, Black Panther essentially made this genre one which is recognized in the popular imagination, not only in discourses of those who engage with the genre. Black Panther's success however, can be read and questioned in a number of ways.

\section{On Heroes and Comic Super Heroes}

The character of Black Panther first appeared in Marvel comic books in 1966 as part of the Fantastic Four and his first film appearance in Captain America: Civil War (2016). As Brent Staples writes, the comic was not at all radical when it was first introduced, but, the subtext was. Black Panther's alter ego, $\mathrm{T}^{\prime}$ Challa, was characterized in the same way as experienced in the film and this rendition of the character "begs to be read as a critique of both the western slave trade and (... ) prevailing attitudes 
of superiority through which Westerners have long viewed Africans" (New York Times, Staples 2018). Staples's position is not one which celebrates the 2018 film wholeheartedly but rather shifts our aspect to what may have been a radical subtext (which worked alongside the Civil Rights Movement) to and of 1960s North America and which problematizes the character both in terms of filmic characterization as well as popular appeal beyond the film. Staples notes that public perception of the character was often conflated with the radical black political party of the same name and thus always remained "a second-tier comic that often teetered on the verge of cancellation" (Staples 2018). In his work on Batman and Captain America, Christian Russell argues that comic book heroes are "role models for readers" (Russell 2014, p. 122). Russell's thesis identifies specific "heroic moments" in relation to the characters of Batman and Captain America, arguing for a relation that audiences are able to, and need to draw among three moments: teaching moments, archetypal moments and ideal moments (Russell 2014, p. 122). Russell's tracing of the histories of comic books and the need for them for audiences is a useful approach when he defines the aforementioned moments that an audience may experience while watching a comic: "'teaching moments', defined as moments where the heroes act in a manner that is obviously aimed to teach a lesson, 'archetypal moments', wherein a hero acts in a very traditionally heroic way, based on the Jungian 'hero' ... and 'ideal' moments, when a hero appears in a manner that is meant to inspire the reader to act in the same way" (Russell 2014, p. 127). If we take Russell's three defining characteristics and apply them to Black Panther, we are, throughout such an analysis, confronted with the question of the representation of race and the disruption of what is essentially a white, heteronormative assessment of the white, heteronormative super hero. As is the case with science fiction scholarship, much of the existing theorization exists about and in relation to science fiction cultural work (films, books, comics and other narratives) that imagine(s) a future without black people (Yaszek, Tate, Dery). And, as Staples argues, the character always existed in the Marvel stable but was never realized to the same degree as some of the other superheroes.

This critical perspective posits blackness within science fiction as a genre and re-articulates the genre itself, hence Afrofuturism. However, this paper shows how Black Panther is less of an Afrofuturist work than a neatly commoditized Marvel comic which rides on the coattails of popular black culture, and a popular ability to perform 'being lit', more generally.

\section{T'Challa and the 'Never Colonized' Nation of Wakanda}

After the death of T'Challa's father, the up until then ordinary young man has to return home to Wakanda to take up his position as King. For a film in which geography and space are so important, the film relies on the binary of global North and global South, cementing the film in a rather familiar, albeit complex geopolitical power relationship. T'Challa's having to go home is also not unfamiliar in diasporic narratives, both African, Caribbean and other. It echoes a host of 'African' fables and diaspora literatures which hold the diaspora at its core. ${ }^{1}$ I use the term 'never colonized' in an attempt to emphasize the distinction made by the film itself, that Wakanda was never colonized and that there is a form of reverence in this position that positions it differently from other African nations. As is commonplace in comic book adaptations, audiences are invited to see their super heroes as ordinary first and then see them morph or change into their alter ego characters. This pattern continues throughout Black Panther. After the death of his father, King of Wakanda, T'Challa returns home to a nation that is firstly, African, secondly, technologically more advanced than the rest of the world and thirdly, absolutely exceptional. The exceptionality of Wakanda rests on the country's centuries'-long invisibility. This seeming invisibility alongside Wakanda's storage of a powerful fictional mineral, Vibranium, means that they house power that no other nation knows of. The uncovering of this hidden mystery of Wakanda's power in Vibranium, is the subplot to the film, one which stands in for various real national narratives of power too. Part of these exceptional positions are portrayed through

1 See works by authors, Ben Okri, Tsitsi Dangarembga, Chimamanda Adichie. 
characters however, part of the framing takes place therough cinematography which often highlights specific images through mise-en-scène which emphasizes Wakanda as different from other places (See Figure 1). A location shot is shifted to rely on the fact that it is not recognizable to affirm Wakanda's exceptional position in the viewers' imaginations.

The primary plot, however, centers on T'Challa and his ability to become the leader of Wakanda, a noble position. Reviewers have noted the highly gendered position of power in that although $\mathrm{T}^{\prime}$ Challa is the leader, women run the army and, $\mathrm{T}^{\prime}$ Challa's younger sister manages the laboratory that essentially creates all kinds of things out of Vibranium. From the outset thus, while Wakanda may seem to display the traits of an intersectional uncolonized African reality, there is no active disruption of some of the traditional perceptions around gender and patriarchy, a point which the paper returns to later.

The latter point notwithstanding, Wakanda presents us with a way to think about the intersection of past and present and invites us to grapple with historical and contemporary geopolitical positions and representations of such issues. In this interrelationship between past and present, the existence of Wakanda makes it permissible to imagine an African nation as truly powerful. However, this celebration is short-lived, for the mystery of Wakanda overrides the celebration. This mysterious element is exemplified when villain Erik Killmonger (Michael B. Jordan), who we later learn is also Wakandan and T'Challa's first cousin, steals Vibranium from a British museum. In his brief interaction with a white curator at the Museum, an expert on African artifacts which they both look at through the thick glass cubes in the gallery space, we learn that 'ancient Africa' is a mystical place. He corrects her by telling her that the artifact they discuss belongs to present day Wakanda. His tone and dialogue explicitly make her out to be ignorant in her arrogance and places a colonial narrative of Western pillaging at the forefront of the fictional Marvel adaptation.

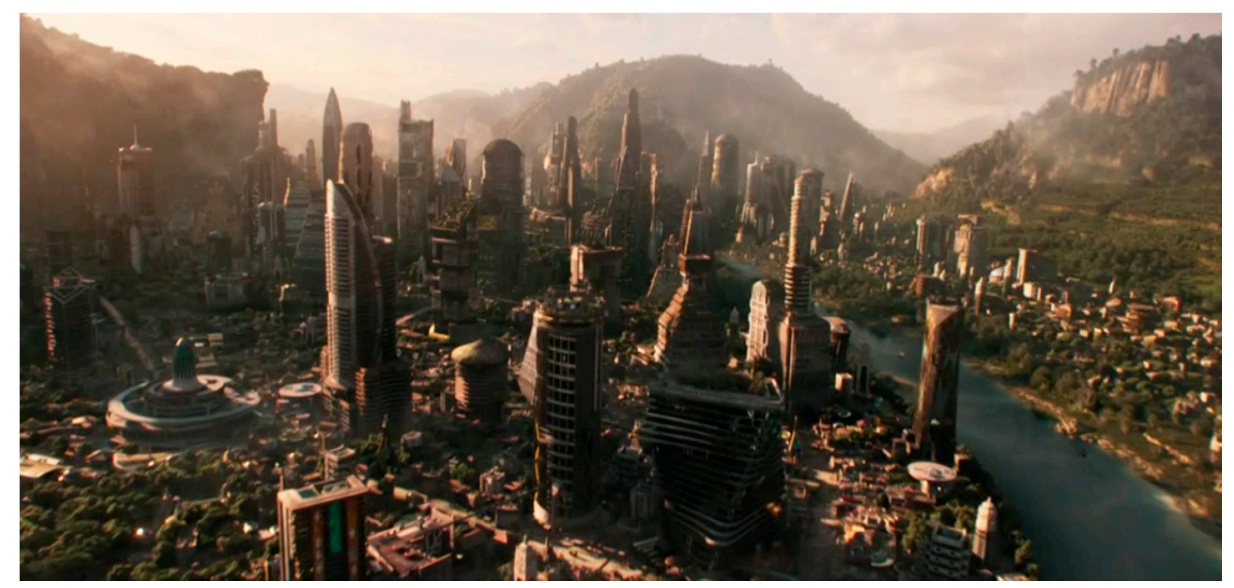

Figure 1. Aerial shot of Wakanda (Taken in accordance with fair use of images rights for the film Black Panther, Ryan Coogler, 2018, Marvel).

The opening of John Akomfrah and Edward George's 1993-1994 piece, Last Angel of History, starts with the following:

In the future, like racial memory, black futurology may be allotted rooms on the Internet. Housed in cyberspace vaults marked 'tomorrow', coded with a connective emblem, this past, our present, could be the key to making sense of the future, the present of some yet unborn black person. Akomfrah and George 1996, reprint of 1993 piece in Chimurenga Chronic 2013) ${ }^{2}$

2 This piece appeared in the Chimurenga Chronic in December 2013 archived under Arts\& Pedagogy, Healing and Bodies. 
The piece by Akomfrah and George formed a loose script for what became a film by the Black Audio Film Collective, titled The Last Angel of History (1995) and seems fitting in relation to the opening scenes of Black Panther. In Akomfrah and George's articulation about what a black future looks like, we are invited to imagine the interrelationship of black past(s), present(s) and future(s). In Black Panther, we are invited to view a kind of spectacularization of blackness, a kind of exceptionalism both celebrated and desired in ways that have seemingly never been experienced in relation to blackness. This consideration around exceptionalism seems to me to be a consideration of ideas and politics covered in great detail already and which has specific links to what Paul Gilroy theorizes in The Black Atlantic: Modernity and Double Consciousness (Gilroy 1993). Specifically, the issue of fictional Vibranium in a fictional Wakanda is telling of a much deeper seated issue around Western Modernity, a project of pillage and warfare in which the West was always in a position of power and which is still evidenced today, taken apart, in some ways in the story about and around Wakanda. The larger narrative suggests that perhaps there are other secrets in Africa that muddy an already complex colonial narrative, in some ways, I argue, delegitimizing various existing histories of colonialism not written by white settlers.

Paul Gilroy's attention to thinking about modernity for the black subject as a conflict of self is interesting in the context of Wakanda because the Wakandans present themselves as somewhat conflicted but only Killmonger lives that personal double consciousness. (Gilroy 1993, p. 5) The Wakandans are aware that the secret of Vibranium is what keeps them powerful but it is short-lived power that stays within Wakanda. The villain protagonist of course wishes to uncover this secret and to become more powerful with it. Also useful in Gilroy's Black Atlantic is reflection on ideas of nationalism, ethnicity and belonging: for Gilroy, in relation to black British subjects in the United Kingdom, a struggle for belonging, but for this paper, nationalism and belonging is useful to think about who are Wakandans and why they matter. They are themselves 'othered' from other Africans and black people in the diaspora. In both these considerations, the physical idea of the Atlantic and attending discourses of slave movement across the Atlantic is either taken for granted or ignored completely. In the case of Wakanda, the Atlantic as a passage of loss and various national (some would say ethnicized) reconstructions, does not exist. Wakanda remains a fiction for the (real) black subject, both in the film and who watches and who continues to struggle through the rhetoric of belonging and mattering. In some ways then, the betrayed cousin's anger could be read as an attempt at vindication not only for the personal loss and lack of belonging he experiences but also for these same traits that stand in for black people of the diaspora all over the world.

Some of these conflicting elements are present in the scene when Eric Killmonger is presented to the council comprised of elders of neighboring tribes. The positioning of each of the members of council is telling as he is presented to the council as an intruder (See Figures 2 and 3). On identifying himself as one of them, the tone changes. The relationship between ' $u$ ' and 'them', is immediately dismantled in the recognition that he is Wakandan. Initially treated as a threat and danger, through the use of a few phrases in the South African Nguni language, isiXhosa, the council realizes that Eric is a Wakandan. In a shot-reverse-shot sequence mainly comprised of close-ups between Eric and T'Challa, the pair discusses the impasse they find themselves in: that Eric feels that Vibranium could be used to set free the over seven million black people around the world who are still enslaved by Western structures. $T^{\prime}$ Challa dismisses this in a measured way by saying that he is not the king of all those people but the King of Wakanda and that that is not their way. T'Challa's positioning here creates an unfamiliar binary between the dispossessed black diaspora, those somewhat left behind, and the wealthy Wakandans. Wakandans in this film stand in for Africans but they also do not, as Wakanda had never been colonized. It is interesting that they use isiXhosa in moments to speak in what we can only assume to be the language of Wakanda. Even accents lean towards South African sounding ones although it is hard to contextualize this in anything concrete. Partly because of the language and legibility of Wakandans to Wakandans without actually granting that language proper space in the film, I read South African inflections into how Wakanda is able to express its importance and visibility. 


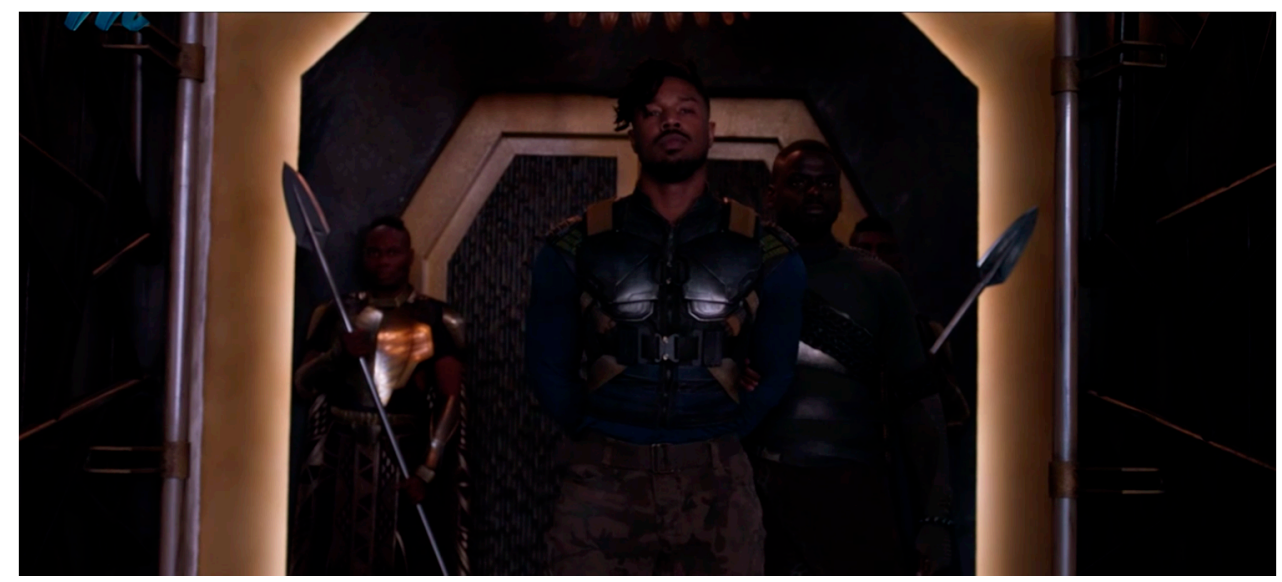

Figure 2. Eric Killmonger presented to council in Wakanda (Taken in accordance with fair use of images rights for the film Black Panther, Ryan Coogler, 2018, Marvel).

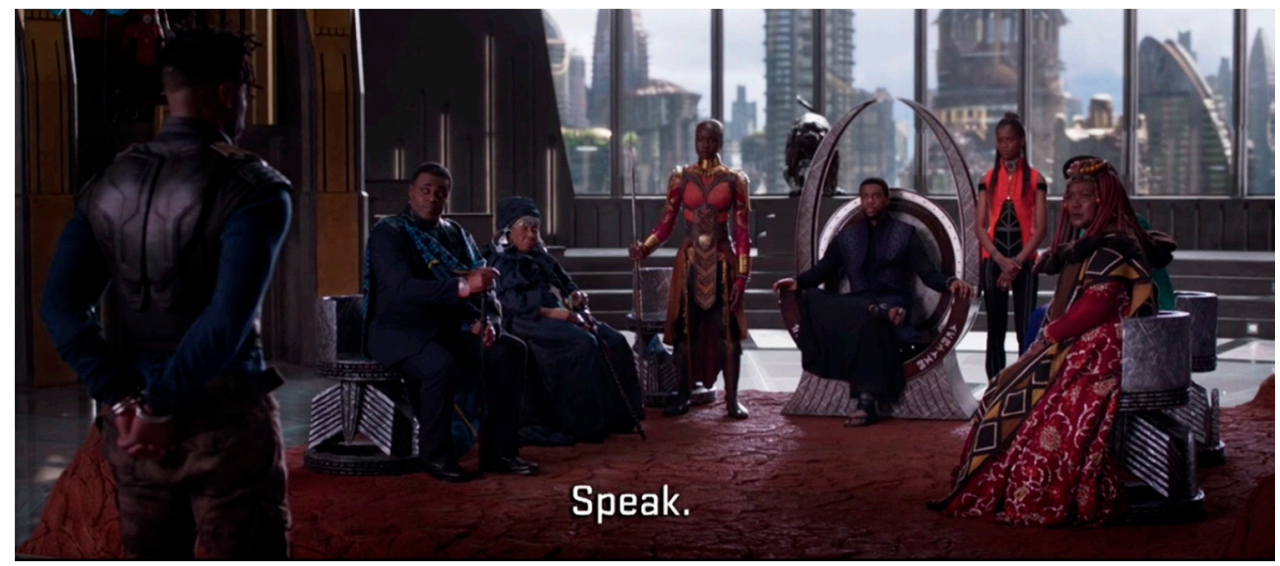

Figure 3. Wakandan council (Taken in accordance with fair use of images rights for the film Black Panther, Ryan Coogler, 2018, Marvel).

Firstly, in the relationship between the cousin and $\mathrm{T}^{\prime}$ Challa (and the nation of Wakanda), we observe an estrangement that has been present for years and this is a similar estrangement experienced between people in the diaspora and those on the continent. This relationship speaks to belonging and nationality as a place of being home. The film addresses the double consciousness about which Gilroy writes. This, being able to show double consciousness and experience through the characters, takes place through a number of characters: cousin Killmonger who grew up in the United States (US) without a father and a sense of belonging, girlfriend to T'Challa, Nakia (Lupita Nyong'o), who has a busy and full life outside of Wakanda doing work that she considers life-altering, and even $\mathrm{T}^{\prime}$ Challa himself. We are also aware that this double consciousness is not new, because we know that Killmonger's father lived in the US too. The conflictedness of being black, woven into the fabric of histories of slavery and displacement, is played out in these roles of questioning who belongs and who does not. This fractured sensibility and identity is only ever articulated by Killmonger, a villain, and thus a character who we are primed not to like and who we are certainly not invited to trust. Killmonger's heartless killing also of the character of Zuri (Forest Whitaker), a kind of Mandela-esque moral large man, further removes any affinity we as viewers may feel for him. Once he kills Zuri and then T'Challa (or we assume he does), the music on the soundtrack changes to a deep and slow staccato beat to indicate change and disruption to what they knew before. It is the start of a new era for Wakanda, confirmed by Killmonger's hard facial expression held in a close-up as he gets presented with the necklace of the King. 
Finally, exceptionalism appears also in the presence of the women who are assumedly powerful in a number of different ways and which the film wants us to know. I want to discuss Nakia (Lupita Nyong'o), Okoye (Danai Gurira) and Shuri (Leitia Wright) in more detail here as women characters who are considered exceptional (also read as 'other'). Sara Ahmed writes of feminism as sensational, "We learn about the feminist cause by the bother it causes; by how feminism comes up in public culture as a site of disturbance". (Ahmed 2017, p. 21) These three women are meant to be read as sites of disturbance, not necessarily to the fictional narrative in which their positions are normalized, but certainly in the affective experience these characters potentially elucidate in a heteronormative patriarchal society. One of the most striking things about Wakanda is that while ruled by a traditional male King figure, its army is comprised entirely of women. These women are dressed in red attire with metal spears and shields as part of their uniform (See Figure 4). They protect the royal family and Okoye, chief of the army and T'Challa's protector, herself pledges her allegiance to the throne before anything else (See Figure 5). After Killmonger takes the throne, we also see conflictedness in Okoye because, while she pledges her allegiance to the throne despite who sits on it, it is clear that she also struggles with protecting someone who is not a 'good' King, and whose intentions appear to be bad. While the royal family, T'Challa's mother, sister, and Nakia flee to a neighboring tribe, Okoye stays to protect the King in her capacity as leader of the army.

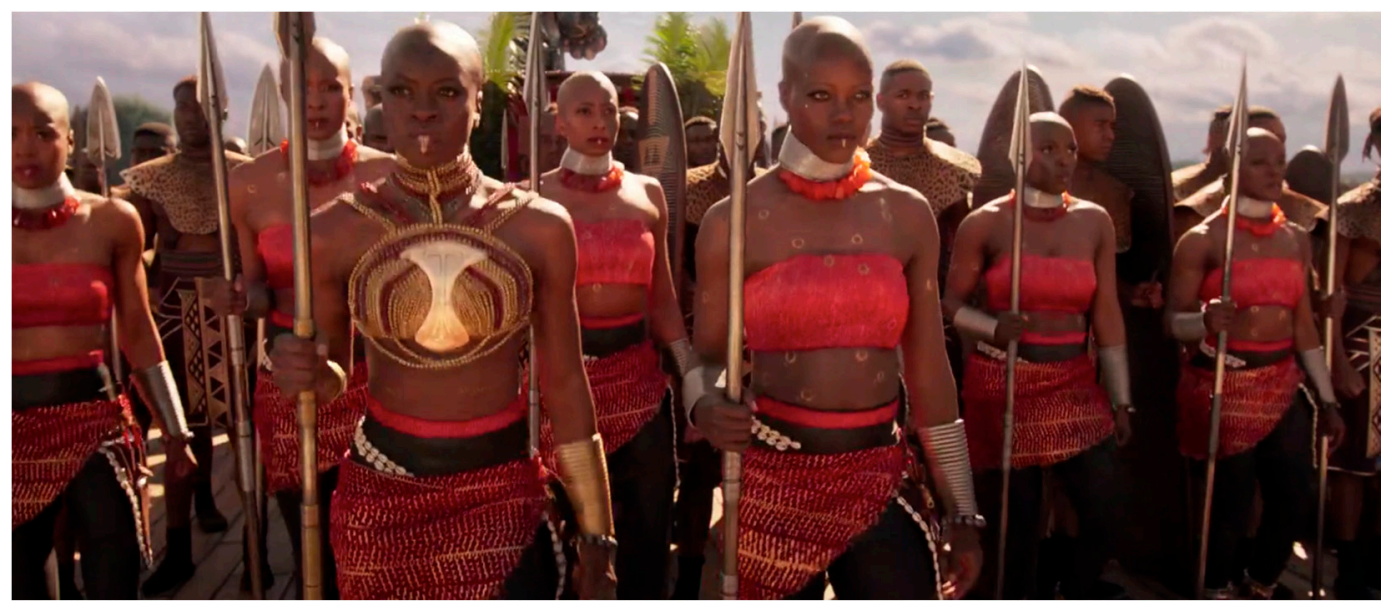

Figure 4. The all-women army led by Okoye who is left front of screen (Taken in accordance with fair use of images rights for the film Black Panther, Ryan Coogler, 2018, Marvel).

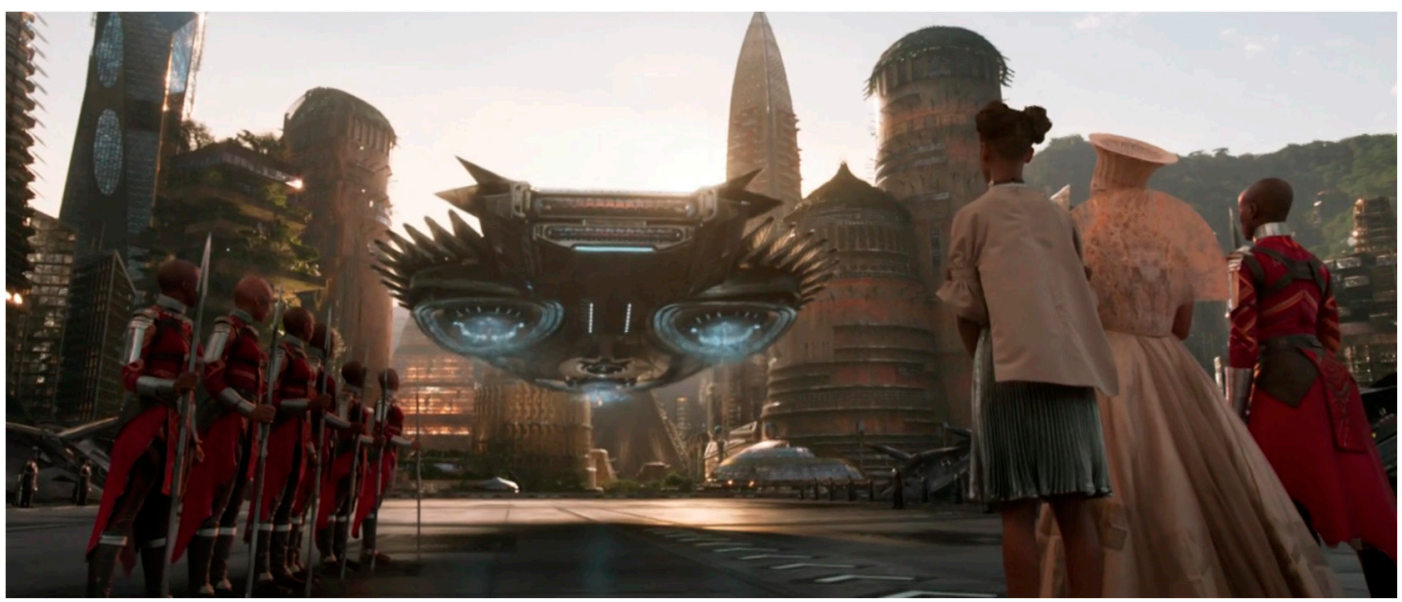

Figure 5. Women of Wakanda - soldiers, Shuri and the Queen as T'Challa lands in Wakanda (Taken in accordance with fair use of images rights for the film Black Panther, Ryan Coogler, 2018, Marvel). 
However, as Killmonger becomes increasingly more deliberate in his dismantlement of the values of Wakanda, we see her discomfort expressed through small facial expressions or related subtle actions, conveyed through close-ups. Nakia explicitly tells T'Challa that she wishes to continue doing her work outside of Wakanda. And Shuri, T'Challa's younger sister seems to head a laboratory that is at the cutting edge of science and technology. She deftly explains how Vibranium works to CIA agent Everett Ross (Martin Freeman), whom she has also essentially healed after a life-threatening gunshot wound. Shuri, Nakia and Okoye are represented as strong, independent women and this thread is interesting because the nation of Wakanda is at the same time a traditional nation, expressed through centuries-old rituals, traditions and ways of doing things that are valued and protected. It is thus interesting that in the midst of this traditionalism, there are all these women who protect the nation. Despite the strong characters, the positioning of this womanhood is never explored further; for example, we never learn why Wakanda has an all-woman army, nor do we learn why or how Shuri knows everything she knows. A rather powerful intention then, feels somewhat misplaced, as though the film comments on patriarchy without really following through on anything. This appears to me to be a typically post-feminist assertion, a popular culture prop that is ever developing and which asserts a sensibility of girls who have power but which never truly offers much beyond. As this was never the intention of such an adaptation which still comes from a stable of Hollywood-type productions, it would also be unfair to make this critique of Black Panther the primary argument of the paper. Nevertheless, it is worth noting that just as the film is/was celebrated for its exceptional positive portrayals of black characters and black women characters, essentially subverting the very notion that black characters are never super heroes, so it has also been celebrated for its representations of black women. Fundamentally then, what is striking about Black Panther is the affective connotations implied in these representations and how these contribute to our awareness and readings of blackness beyond the film, for this is really what the celebration was about. As Kara Keeling writes, "In order to produce value, technological cinematic machines draw on the affective labor of their spectators" (Keeling 2007, p. 96). Drawing on Marcia Landy's work, Keeling argues about Blaxploitation as a genre that,

... in order to argue that Blaxploitation, far from being a misnomer or a regrettable diversion from the progressive history of blacks in American film, signals an intensification (arising out of a specific sociohistorical political formation) of the exploitation via affectivity (already a function of cinematic machines) of an audience (market) presumed to consist of 'black people'. (Keeling 2007, p. 96)

I find many direct parallels between Keeling's argument and the one I wish to expand on here. In the context of Black Panther, this exploitation of affectivity is portrayed through the seemingly positive representations of black people, as was also the case with the Blaxploitation era of films. Also similar to Blaxploitation which appeared in cinema around the period of the civil rights movement in the US, another kind of era of sociohistorical political formations and complexities exists in the United States at present and these should not be overlooked in the context of Black Panther. Furthermore, Keeling's comments on black women figures in Blaxploitation films, "Black Revolutionary Women as blacks with guns" reconfigure even a former critical positioning of women in these films (Keeling 2007, pp. 92-94). Again, similarly to Black Panther, existing scholarship about women characters in the Blaxploitation era often points to how women with guns redefine the woman's role entirely; however, Keeling vehemently suggests otherwise and argues that part of this representation of a supposedly powerful woman also served to over-sexualize black women even further. Her point is to show how the introduction of Blaxploitation was in response to a changing socioeconomic environment in the US and required of Hollywood to show that it could change. Keeling argues that the resolution truly experienced through Blaxploitation films was that as a genre and era in cinema, it came to and has come to stand in for "Black Power", what Keeling describes as "common-sense black nationalism"(Keeling 2007, p. 101). Playing on the same tropes fifty plus years later, Black Panther's positioning of black characters as powerful on cinema screens seems a moot celebration, at best. Perhaps it is more useful to think about a film like this along the lines of how Steven 
Thrasher puts it, that "It's quite appropriate to have a nuanced opinion of Black Panther's politics while also celebrating the unabashed joy of seeing black life depicted through black eyes" (Thrasher 2018).

This essay has engaged with notions of Black exceptionalism and some of the ways in which Blackness is read as exceptional in popular spaces. In particular, it has engaged the film Black Panther and has, alongside that, held the South African post-apartheid space in the framework of critical engagement through discussing Black positionality, diaspora and power.

Funding: This research received no external funding.

Conflicts of Interest: The authors declare no conflicts of interest.

\section{References}

Ahmed, Sara. 2017. Living a Feminist Life. Durham and London: Duke University Press.

Akomfrah, John, and Edward George. 1996. "The Last Angel of History" Reprinted in Chimurenga Chronic (20 December 2013). Available online: https://chimurengachronic.co.za/tag/john-akomfrah/ (accessed on 2 August 2018).

Blignaught, Charl. 2018. Meet Gabi Ngcobo, One of the Most Powerful Curators in the World Right Now. City Press, July 29. Available online: www.24.co.za/Entertainment/Arts/meet-gabi-ngcobo-one-of-themost-powerful-curators-in-the-world-right-now-20180729 (accessed on 30 July 2018).

Brown, Kate. 2018. 'We're not Fixing the Mess': The Curator of the 10th Berlin Biennal, Gabi Ngcobo Refuses to Exorcise Europe's Colonial Ghosts. ArtNet News, June 7. Available online: https:/ /news.artnet.com/ exhibitions/berlin-biennale-10-2018-1298021 (accessed on 25 October 2018).

Dery, Mark. 1994. Flame Wars: The Discourse of Cyberculture. Durham: Duke University Press.

Eshun, Kodwo. 2003. Further Considerations on Afrofuturism. CR: The New Centennial Review 3: 287-302. [CrossRef]

Fanon, Frantz. 1967. Black Skin, White Masks. New York: Grove University Press.

Gilroy, Paul. 1993. The Black Atlantic: Modernity and Double Consciousness. London: Verso.

hooks, Bell. 1989. Talking Back: Thinking Feminist, Thinking Black. Boston: South End Press.

Keeling, Kara. 2007. The Witch's Flight: The Cinematic, the Black Femme, and the Image of Common Sense. Durham and London: Duke University Press.

Nelson, Alondra, and Paul D. Miller. 2006. About Afrofuturism. Afrofuturism. Available online: http:/ /www. afrofuturism.net/text/about.html (accessed on 2 August 2018).

Ra, Sun. 2017. Available online: https://www.youtube.com/watch?v=SnSiQ2xNyy4 (accessed on 17 October 2018).

Russell, Christian. 2014. Heroic Moments: A Study of Comic Book Superheroes in Real-World Society. Explorations, Social Sciences 8: 121-31.

Staples, Brent. 2018. The Afrofuturism Behind 'Black Panther'. New York Times. Available online: https://www. newyorktimes.com/2018/02/24/opinion/afrofuturism-behind-black-panther.html (accessed on 2 August 2018).

Thrasher, Steven. 2015. Afrofuturism: Reimagining Science and the Future from a Black Perspective. The Guardian. Available online: https:/ / www.theguaridan.com/culture/2015/dec/07/afrofuturism-black-identity-futurescience-technology (accessed on 30 July 2018).

Thrasher, Steven. 2018. There is Much to Celebrate-and Much to Question-About Marvel's Black Panther. Esquire. Available online: https://www.esquire.com/entertainment/movies/a18241993/black-pantherreview-politics-killmonger (accessed on 2 August 2018).

Yaszek, Lisa. 2006. Afrofuturism, science fiction, and the history of the future. Socialism and Democracy 20: 41-60. [CrossRef]

(C) 2018 by the author. Licensee MDPI, Basel, Switzerland. This article is an open access article distributed under the terms and conditions of the Creative Commons Attribution (CC BY) license (http://creativecommons.org/licenses/by/4.0/). 